\title{
Interconnections in public transport as a method for delimiting urban functional areas and the settlement hierarchy in Poland
}

Robert Guzik The main aim of the article is to clarify the Jagiellonian University characteristics of the method that determines the in Kraków functional links and gravity towards cities on the

E-mail: basis of public transport connections. The paper robert.guzik@uj.edu.pl delivers a detailed description of the method and

Arkadiusz Kołoś provides examples of its application in empirical Jagiellonian University research conducted by the authors in the years in Kraków E-mail: arkadiusz.kolos@uj.edu.pl 2010-2014.

\section{Krzysztof Gwosdz}

Jagiellonian University

in Kraków

E-mail:

krzysztof.gwosdz@uj.edu.pl

\section{Keywords:}

gravity and potential models, functional links, public transport

\section{Introduction}

Determining the functional and spatial relations between cities and their surroundings is a key area of study in geography and regional science. Nowadays, every piece of geographical space inhabited by humans is under the influence of cities. Amin and Thrift (2002: 1) even conclude that 'the city is everywhere', but the intensity of its presence changes with growth in distance from the centre of the metropolis to the peripheries, which are becoming ever more connected to the central areas. The urban nature of entire areas, and not just individual localities, necessitates addressing urban problems from the perspective of urban regions or functional urban areas (Parr 2005).

Scientific literature and expert studies address a very wide range of problems related to territorial identification of the ties and the areas of influence of cities and

Regional Statistics, Vol. 7. No.1. 2017: 063-077; DOI: 10.15196/RS07104 
towns (see extensive reviews of methods and approaches in Pálóczi et al. 2016 and Śleszyński 2014). Most researchers determine gravitation by measuring the functional links (commuting to work, and less frequently to schools, or travelling to service providers, migration flows), structural indicators illustrating the intensity of selected measures of socio-economic development around an urban locality (e.g. number of businesses per 1000 inhabitants, availability of services), and morphological indicators (e.g. population density). Usually, the latter two groups of indicators, which result from the influence of the core city, play an auxiliary role, but in some studies, in the absence of current data about functional interactions, they have been treated as primary indicators (e.g. ESPON 2007, SmętkowskiJałowiecki-Gorzelak 2009).

As Sleszynski (2016: 83) indicates a major problem in the delimitations, and generally, in all spatial research on socio-economic development, is obtaining data that reflect the actual intensity of the phenomena and processes. In Poland in particular, between 1991 and 2006, the lack of data on commuting, which is a classic indicator for delimiting the impact zones of cities, forced researchers to develop alternative research methods (see Śleszyński 2013, Siłkowska et al. 2016). One of these includes determining the functional links and gravity towards cities on the basis of public transport connections. The goal of this paper is to describe the characteristics of this method, illustrate its use with examples, and present a discussion.

The paper is organised as follows. The second section provides the detailed characteristics of the method, preceded by a short discussion of the gravity model. The third section provides examples of the application of this method in empirical research conducted by the authors in the years 2010-2014. The next section presents a discussion of the strengths and weaknesses of the method and summarises the main findings.

\section{Public transport links: presentation of the method}

Based on the timetables of the companies running the public transport system, each location can essentially be identified as gravitating towards a location situated higher in the hierarchy of settlements using two methods. The first one is to determine which town has the greatest number of incoming connections or most convenient connections in terms of travel times and regularity. The effect of this procedure can be illustrated in a graph. The main drawback of this method is its binary nature, which does not allow the inclusion of gravitational forces to a greater number of localities. The problem is solved by a method based on the gravity and potential models, which not only allows the multidirectional nature of the gravity to be taken into account, but also to be measured and quantified. It should be added that public extra-urban bus transport in Poland is provided almost exclusively by commercial

Regional Statistics, Vol. 7. No.1. 2017: 063-077; DOI: 10.15196/RS07104 
companies. Thus, it can be assumed that the connections (supply in the form of the connections in the timetables) provide a relatively good match with the demand for transport services. The supply side in Poland is very flexible, because carriers are free to launch and discontinue scheduled trips at any time, and are only limited by formal procedures. The presentation of the method used by the authors in a series of regional studies in Poland (see Guzik 2012, Guzik-Kołoś 2015, Guzik et al. 2010, 2016) will be preceded by a brief presentation of the potential model.

\section{Introduction to the potential model}

The gravity and potential models are the basic spatial interaction models used in geographical and economic research. They were developed by adapting the concept of the population potential model proposed by Stewart (1941), which quickly became a fundamental model of social physics. A broad overview of the evolution of the models is presented by, among other authors, Chojnicki (1966), Vickerman (1974), Pooler (1987), and Guzik (2003). One interpretation of the value of potential is to consider it as a measure of spatial accessibility. The concept behind the model is as follows: the potential of a phenomenon in a given location is the sum of the partial potentials of all the other places studied that exert their influence on the location. For example, the partial potential exerted by locality $j$ on locality i, i.e. $V_{\mathrm{ij}}$, depends on the mass of locality $\left(\mathrm{M}_{\mathrm{j}}\right)$ and the distance between the localities $\mathrm{d}_{\mathrm{ij} \text {. The }}$ general formula of the potential model is as follows:

$$
V_{i}=\sum_{j=1}^{n} \frac{M_{j}^{Z}}{d_{i j}^{b}}
$$

where: $\mathrm{Vi}$ - potential at point $\dot{i}, \mathrm{Mj}$ - mass of point $j ;$ dij - distance between points $i$ and $j ; \mathrm{b}$ - distance decay exponent; $\mathrm{z}$ - locality $\mathrm{j}$ mass exponent.

The mass of the locality will represent the phenomenon for which the potential is calculated; for the population potential, it will be the number of people, and for the availability of pharmacies for instance, it will be the number of pharmacies. For human capital, the mass will be the number of people with specific educational attainment. Using the exponents both for the mass (size of locality) and the distance allows the spatial relationships to be determined in a more realistic way and the nonlinear increase/decrease in the scale of the spatial interactions between localities $i$ and $\mathrm{j}$ to be adopted. The exponents are adjusted to the phenomenon studied. It was assumed that distance decay $\left(\mathrm{d}_{i j}\right)$ is exponential in nature - the most common solution is to divide the mass by the square of the distance, which was also the case in this study. The measure of distance used in the study is kilometres. The mass exponent $(z=1)$ was waived as it is better suited to transport studies, and the lack of adequate empirical studies does not permit specific values of the parameter to be adopted.

Regional Statistics, Vol. 7. No.1. 2017: 063-077; DOI: 10.15196/RS07104 
The use of the potential model gives rise to a number of specific problems which need to be addressed. They include:

a. choosing the points for which the potential is to be calculated,

b. the problem of area boundaries,

c. the own potential of localities.

A convenient option is to choose one representative point for each unit (town, municipality /gmina/, county /poviat/) to which the mass of that locality (phenomenon) will be assigned and from which the distance to the other points will be calculated. The point was placed in the centre of a communal town or in the centre of a poviat capital. For rural municipalities / rural gminas/ surrounding a city with their headquarters in the city, locating the point for the rural municipality and determining the distances between those municipalities is problematic. In order to calculate the external potentials, it was assumed that both points have the same location, while the distance between them was calculated as two-thirds of the radius of a circle having the summative area of the city and the rural municipality.

As the potential is the sum of the impacts exerted on the municipality, municipalities located on the border of an area will always have a lower potential (no influences from outside of the border). While sometimes this is justifiable for the state border (given their low penetrability), disregarding the mutual interaction for administrative borders inside a country would distort the actual picture of the phenomenon. Therefore, all the potentials calculated in our study (at regional level) take into account the potential exerted by adjacent areas and areas situated at a distance of $25 \mathrm{~km}$ from its borders. Including a larger area would be pointless because the potential decreases (exponentially) with increase in distance.

The problem of own potential includes the problem of establishing the distance of the municipality from itself. The most common approach is to assume that $\mathrm{d}_{\mathrm{ii}}=1$, i.e., a municipality's own potential equals the size of the phenomenon in the municipality. Such a solution is not always good for assessing accessibility - for example, all doctors or pharmacies in the capital city of a region are assigned to a single point with a very high own potential and accessibility, which, in fact, does not occur anywhere. If the capital city of a region was divided into four units and distances $\mathrm{d}_{\mathrm{ii}}>1$ appeared between them, then the sum of the potentials for those four units would be lower than for a single point. Therefore, it can be assumed in potential studies used to assess accessibility that $\mathrm{d}_{\mathrm{ii}}=1 / 2$ of the radius of the circle representing the area of the unit (municipality), which is the case in the present paper.

The results of the potential model can also be used for comparing the availability of a phenomenon and saturation with the phenomenon by comparing the area of the potential (the potential difference or quotient method). For example, if the share of a municipality in the population potential of a province (województwo) is $0.5 \%$, and its share in the potential of the number of doctors is $1 \%$, this means that the availability there is twice the average availability in the whole region. To some

Regional Statistics, Vol. 7. No.1. 2017: 063-077; DOI: 10.15196/RS07104 
extent, the potential quotient method eliminates the boundary problem and completely eliminates the problem of own potential (two potential areas calculated in the same way divided by each other).

\section{Database of connections in public transport}

In order to apply the gravity and potential models to determine gravitation in public transport, it was necessary to build a database of connections. The study was based on the timetables of all public and private transport operators. In the example from Pomorskie Province presented in this paper (Guzik 2012, Guzik-Kołoś 2015), a database was created with a record for each city and rural locality in the province $(\mathrm{n}=1753)$ and for 63 towns (municipality seats) in the poviats of adjacent provinces bordering on Pomorskie Province. For each of these cities and towns, the following are determined separately for (i) rail connections, (ii) bus links in transport organised by municipalities or their associations (in Poland, this actually means only city transport), and (iii) other bus routes organised by private carriers (on a commercial basis): the number of outgoing trips (separately for three time periods: $4^{01}-6^{00}, 6^{01}$. $8^{00}, 8^{01}-10^{00}$ - that include the morning peak traffic), number of trips throughout the day, and the number of trips on Sunday, as well as the travel times to:

a) the capital city of the region (Gdańsk);

b) the poviat capital;

c) all the other towns in the poviat,

d) other cities and towns in Pomorskie Province subject to the restrictive conditions outlined below; and

e) cities and towns lying outside of Pomorskie Province subject to the restrictive conditions outlined below.

In the case of rural localities for which the links with the cities and towns referred to in points (d) and (e) were determined, only those connections were included that do not cross a city bigger than that with which the connection exists (in line with the principle of indirect possibilities). The above problem concerns rural localities on transit routes crossed by the trips, and small towns situated along such routes. If no restrictive condition was used, their estimated forces of gravity would be well above the actual ones. The complexity and labour intensity of the procedure makes it reasonable for the study to be narrowed down to the morning traffic peak, which allows the actual connections and gravitation to places of work, education, and services to be determined in the best possible way.

\section{Public transport connection indices}

The resultant databases consisted of 66,572 public transport connections on weekdays as of the second half of 2014. Using the databases, two key indicators were constructed:

Regional Statistics, Vol. 7. No.1. 2017: 063-077; DOI: 10.15196/RS07104 
1. A connection index which is the sum of all the connections of a given town weighed by the following multipliers:

a. Time periods: 401-600 (number of connections $\times 2$ ), $6^{01-800}$ (number of connections x 3), $8^{01}-10^{00}$ (number of connections x 1).

b. Means of transport: rail transport (number of connections x 3), city transport (number of connections x 1.75), bus transport (commercial) (number of connections $\mathrm{x} 1$ ).

2. Lines operated index: defined as the average number of public transport lines operated on all days of the week (the number of lines operated is the number of cities and towns accessible via direct connections by public transport).

Using the databases of public transport connections in Pomorskie Province, intercity links were also analysed.

\section{The potential model - gravitation in public transport}

When using the potential model to identify interactions in public transport, it was assumed that the gravitational forces are proportional to the size of the attracting location (the principle of gravity) and connections (trip number factor), and inversely proportional to the distance as expressed by travel time. Therefore, for any rural locality (in Pomorskie Province $-1,753$ localities), the gravitational force from that locality to every city that could be directly reached from that locality were determined based on the timetables and the potential model, and included in the above database. The distance measure adopted $\left(\mathrm{d}_{\mathrm{ij}}\right)$ was the weighted average travel time in minutes for all trips. Instead of the mass exponent, use was made of the gravitational attractiveness multiplier based on the location's position in the settlement hierarchy $(k)$ : the gravity values to the capital city of the region (Gdańsk) were multiplied by 2; to Gdynia (the second largest city of the region and of the metropolitan Tri-City) by 1.6; to former provincial capitals (Słupsk, Bydgoszcz, Elblag, Piła) by 1.5; to their own poviat town by 1.4; to poviat capitals other than their own poviat town by 1.2; and gravitation to other towns was assigned the multiplier of 1 . In addition, a root of the trip number index (connection number index weighted by the time of day and type of transport) was added to the numerator of the potential model. The authors decided to use it because an increase in the number of trips does not translate into a linear increase in gravity. The index of the radical was chosen arbitrarily (here 1.8) as the square root (that is most often used in literature) would excessively flatten the significance of the number of trips. The resultant potential model formula is as follows:

$$
V_{i}=\sum_{j=1}^{n} \frac{M_{j} k^{1,8} \sqrt{P_{i j}}}{d_{i j}^{2}}
$$

Regional Statistics, Vol. 7. No.1. 2017: 063-077; DOI: 10.15196/RS07104 
The value of the potential is proportional to the size of the location (large cities strongly attract small towns, with very poor attraction in the opposite direction) and to the number of trips per day, and is inversely proportional to the distance. As the distance grows, the number of spatial interactions declines. The potential was calculated for all the pairs of locations: rural locality-city and city-city (if there was a connection between them by public transport). Calculating the forces of gravity is the most difficult for cities, as it involves the problem of measuring their gravity towards themselves (own potential). It was assumed here that the distance is always 10 minutes, and the strength of the connection was arbitrarily assumed to be 100 trips for towns other than poviat towns, 200 for poviat towns, and 300 for Gdańsk, Gdynia, and Słupsk. For example, in Bytów, 93\% of the population is assigned to the town itself - the high value is attributed to the large distances and poor connections, which cause the potential and gravity to other cities to be very poor. Another extreme example is Żukowo, which is located in the 'shadow' of the potentials of Gdańsk, Gdynia, and Kartuzy, as a result of which only 9\% within the town gravitates towards the town itself.

Table 1 shows an example of the calculation for Borzytuchom's potential in the Bytów poviat.

Table 1

Calculation of gravity forces for Borzytuchom (the potential model)

\begin{tabular}{l|c|c|c|c|}
\hline \multirow{2}{*}{ Parameters } & \multicolumn{3}{|c}{$\begin{array}{c}\text { Cities and towns with direct connections } \\
\text { with Borzytuchom (attracting ones) }\end{array}$} \\
\cline { 2 - 5 } & Bytów & Słupsk & Chojnice & Bydgoszcz \\
\hline 1. number of attracting city population & 17,537 & 98,647 & 41,302 & 356,177 \\
2. attraction multiplier (administrative attractiveness & 1.4 & 1.5 & 1.2 & 1.5 \\
factor) & 33.2 & 18.8 & 2.7 & 2.7 \\
3. root of connection index $P_{i j}$ & 446 & 7,293 & 15,374 & 105,502 \\
4. square of average time distance $d_{i j}$ & 1,828 & 381 & 9 & 14 \\
5. contribution to the potential (influence) & 81.9 & 17.1 & 0.4 & 0.6 \\
6. percentage of total potential & 762 & 159 & 4 & 6 \\
7. population of Borzytuchom identified as gravitating & & & & \\
towards attracting cities and towns & &
\end{tabular}

Source: Guzik 2012, revised.

The gravitational force of Borzytuchom to Bytów equals the number of inhabitants of Bytów [row 1] multiplied by the attractiveness factor $\mathrm{k}$ [row 2], which represents the attracting mass in the gravity model multiplied by the root of the connection index [row 3]. In the next step, the result is divided by the squared average time distance [row 4], which expresses the distance decay. The resultant number is 1828 [row 5], which expresses the power of attraction of Bytów. If we

Regional Statistics, Vol. 7. No.1. 2017: 063-077; DOI: 10.15196/RS07104 
add the rates of attraction of Borzytuchom to all the cities and towns with which it has connections, we will be able to calculate the share for each town, which is $81.9 \%$ [row 6] for Bytów. It can be assumed that this percentage of the town's population gravitate towards Bytów, which translates into 762 inhabitants [row 7]. After calculating the above values for all the 9350 interactions, the numbers of population of all the towns that gravitate towards Bytów (or any other town) can be added up to illustrate the size of its hinterland or service strength.

\section{Examples of the use of the method in empirical research}

The authors used the method described above to study the rank of towns in the settlement network and delimit functional urban areas in several Polish regions, including the Małopolskie (Guzik et al. 2010), Pomorskie (Guzik 2012, GuzikKołoś, 2015), and Warmińsko-Mazurskie Province (Guzik et al. 2016). The use of the method is illustrated below on the basis of the Pomorskie Province example.

\section{Determining the hinterland and service rank of cities and towns in Pomorskie Province - based on gravitational forces in transport}

The graph (Figure 1) presents the above-mentioned connection indices (cf r. 2.3) for all the cities and towns of Pomorskie Province in the years 2011-2014. The green lines mark the boundaries of the class intervals, and the orange rectangles indicate the areas within which (as was predicted) the cities and towns should be located - regional and supra-regional cities (marked with the letter ' $R$ '), sub-regional towns (' $\mathrm{S}$ '), transit towns ('T'), and poviat towns ('P').

In the years 2011-2014, Pomorskie Province shows strong and growing discrepancies in the scale and quality of intercity interactions. The province was clearly divided into the north-eastern part, which was developing (in terms of relations), and the south-western part, where the strength and extent of the intercity links were declining. There is a noticeable increase in the strength and extent of links in the Tri-City (Gdańsk, Gdynia, Sopot) and the other cities of the metropolitan area, especially those lying along the Lębork - Gdynia - Gdańsk Tczew railway line. The changes in the intercity links are symptomatic of a growing metropolisation of the area, and the growing supra-regional role of Gdańsk and Gdynia. The other cities, including sub-regional ones (Chojnice and Słupsk), saw a decline in at least one of the indices. In only a few poviat towns did the strength and extent of their interactions correspond to their rank in the hierarchy. 
Figure 1

Number of connections and lines served in the cities and towns of Pomorskie Province

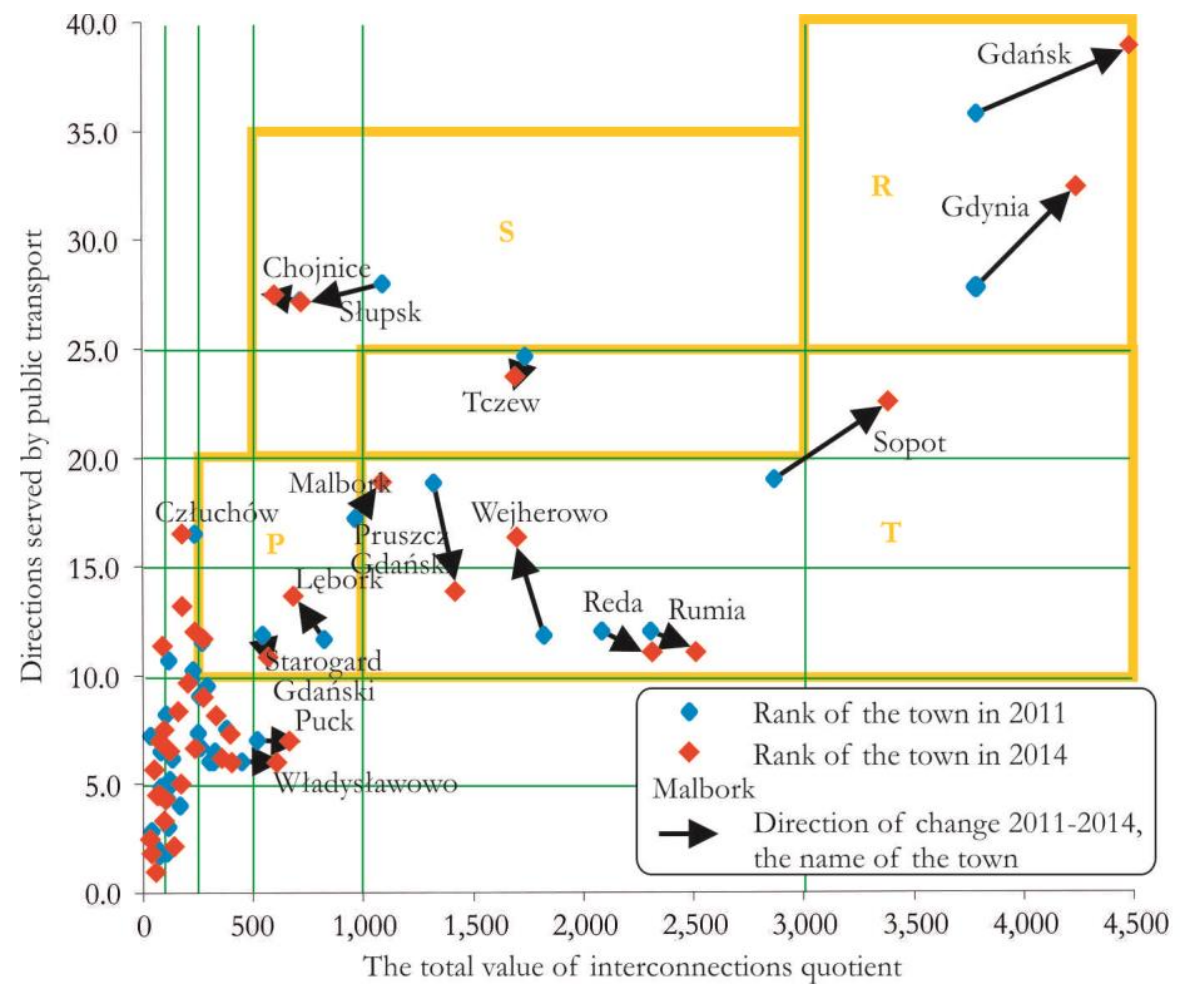

Source: Guzik-Kołoś 2015

Determining the directions and scale of gravitation allows the proportions of each locality's population that gravitate towards the cities where services are provided to be established; then, after adding them up according to the centre of gravity, the size of their hinterland or, in other words, their service potential can be determined. The results for all the cities and towns in Pomorskie Province are presented on a map (Figure 2). It must be pointed out that the method adopted, in which the gravity from a given location is matched to the respective superior units (according to their attraction potential), reflects the actual gravitation more accurately than the greatest flow method, whereby the cumulative gravitation from a given unit is assigned to the unit with the greatest incoming streams.

Regional Statistics, Vol. 7. No.1. 2017: 063-077; DOI: 10.15196/RS07104 
Figure 2

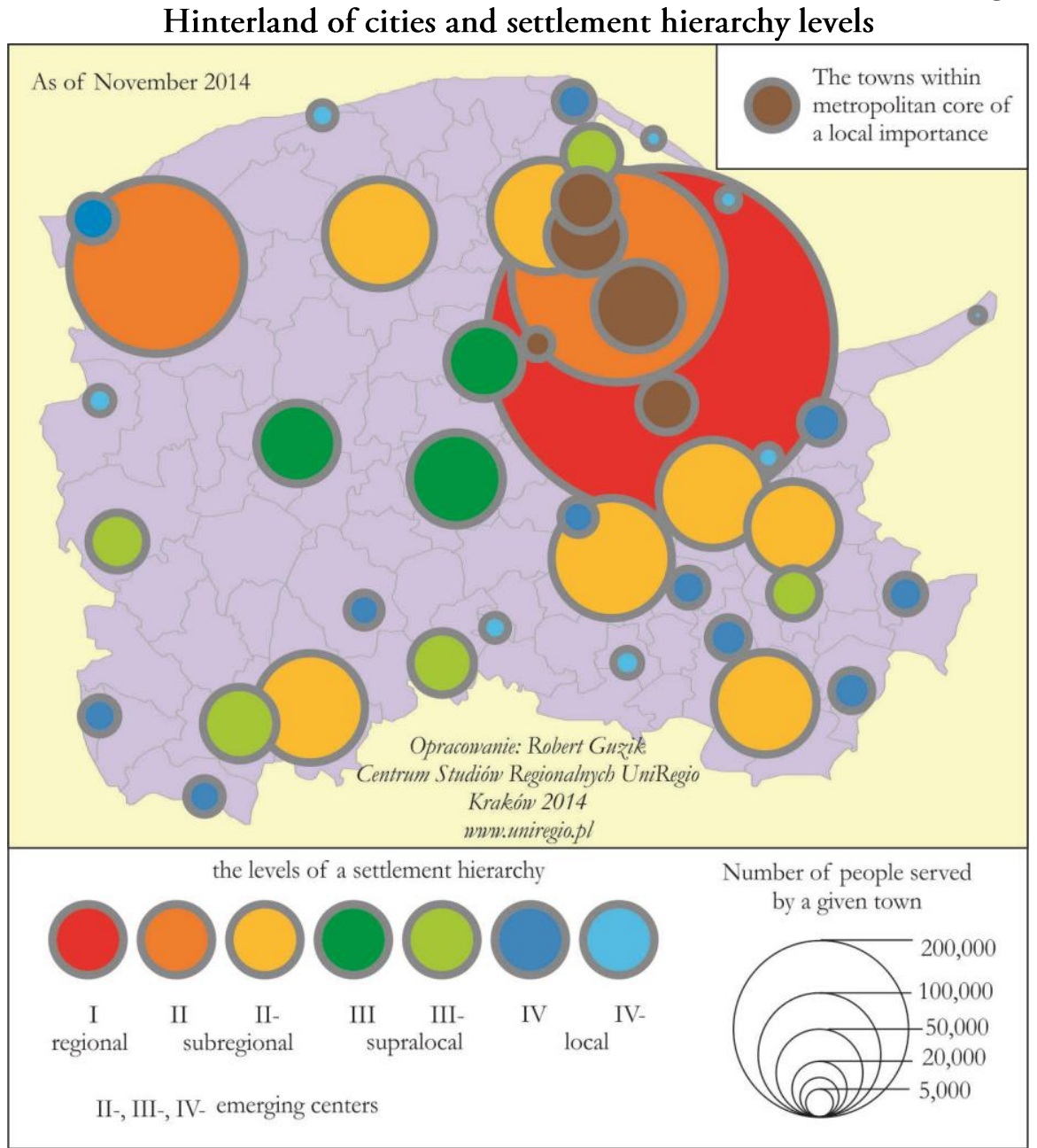

Source: Guzik-Kołoś 2015.

\section{Delimitation of urban regions}

The gravity model constructed may also be used for delimiting the areas that serve cities and towns at different levels of the service hierarchy. The areas may also be considered to be urban regions. This study presents an example of such delimitation on the local level (around each city). The catchment areas were delimited at a municipality level (the smallest units of the basic administrative division in Poland). The averaged gravity for municipalities reflects the gravity of the individual localities weighted by their populations. Even though the delimitation was carried out separately (each municipality is assigned to the area of one city only),

Regional Statistics, Vol. 7. No.1. 2017: 063-077; DOI: 10.15196/RS07104 
given the multidirectional nature of the gravity, secondary directions of gravity were also determined.

Figure 3

\section{City service areas at the local level}

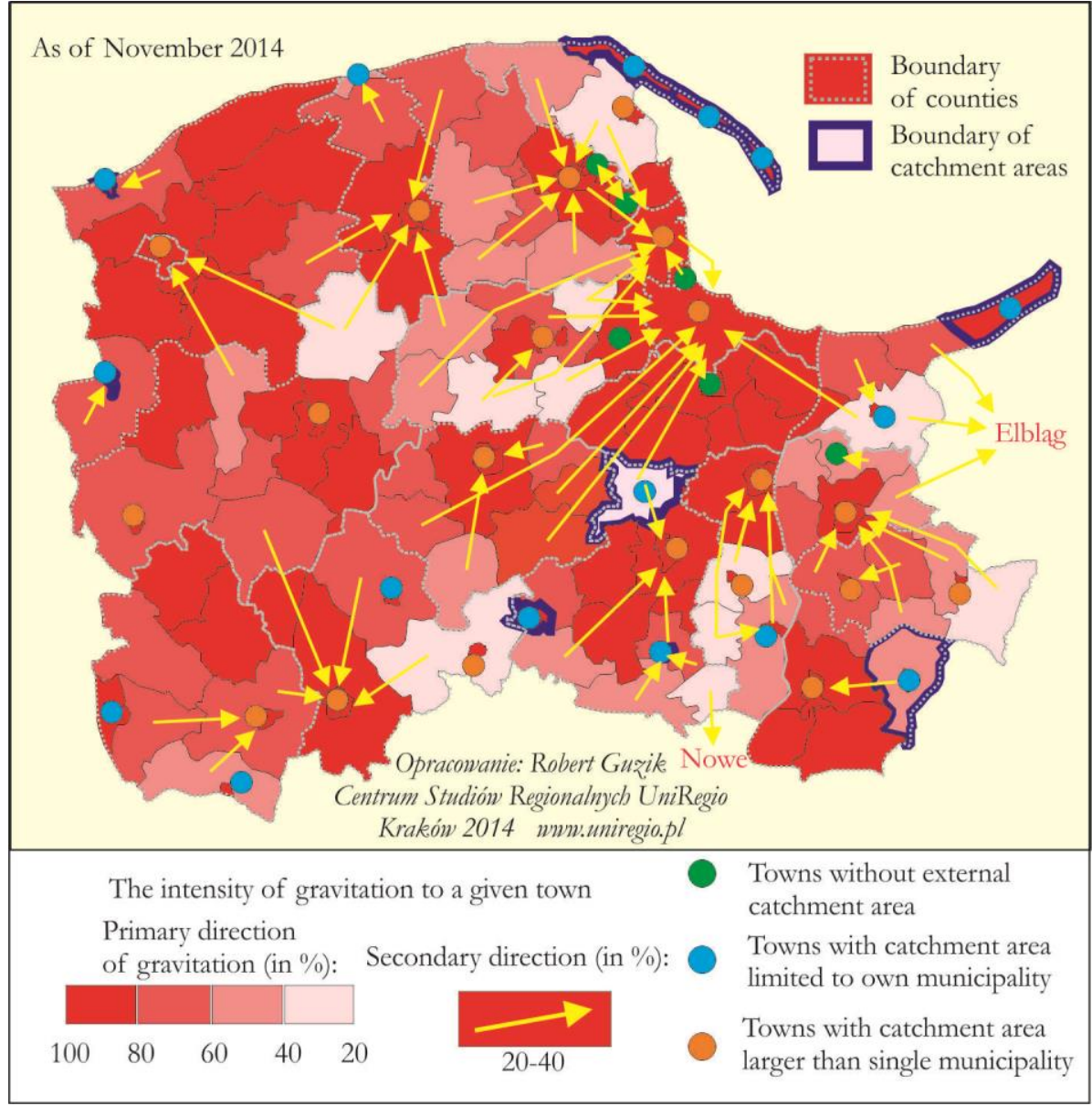

Source: Guzik-Kołoś 2015.

Delimiting the service areas at a local level (Figure 3) showed that there is a group of towns that have no external service area except for that within their own borders - they act as local service areas for themselves (e.g. the towns of the Hel Peninsula). No service areas were delimited around the strongly integrated cities of the Tri-City, either. In addition, the service area around other small towns includes only the rural part of the municipality to which they belong. Around the other towns, the service areas delimited include at least two municipalities. The largest service areas at the local level were delimited around Słupsk, Bytów, Gdańsk,

Regional Statistics, Vol. 7. No.1. 2017: 063-077; DOI: 10.15196/RS07104 
Starogard Gdański, and Lębork. This results, on the one hand, from strong gravitation and links (Gdańsk, Starogard Gdański), and on the other, from the low density of the urban network and poor connections (e.g. Bytów).

An analysis of the secondary directions of gravitation shows that the localities that perform local functions for a larger number of municipalities (in the map in Figure 3, they are shown as the localities with larger numbers of incoming yellow arrows), concentrate around the key urban locations of the region. The cities identified most often as a secondary gravity direction on a local level are: Gdańsk, Gdynia, Wejherowo, Lębork, Malbork, Chojnice, Starogard Gdański, and Elblag from the Warmińsko-Mazurskie Province, which has the rank of a sub-regional locality.

The method can also be used to delimit regions at supralocal and regional levels.

\section{Discussion and conclusions}

Catchment areas are most often delimited by measuring a variety of functional interactions. In practice, given the types of data available, the most commonly used indicators are those related to commuting to work or school (Gruchociak, 2012, Śleszyński 2014). In Poland, when working on the Polish National Spatial Development Concept 2030, exclusive use was made of the labour market interaction indices available in public statistics and the imperfect indices of migration or structure of the economy (cf. Śleszyński 2012, 2013). According to the authors of the study, attempts to determine the actual gravitation should also include analysing trips to schools, retailers, and service providers, and perhaps also incidental (family and social) ties.

The method presented in this paper is based on the assumption that the public transport network is organised in a commercial manner; thus the supply of public transport corresponds to the actual demand. This allows the gravity to be mapped in a more accurate way than on the basis of commuting to work or school alone. First of all, the method takes into account the links related to broadly defined services. The regional studies conducted by the authors across Poland have shown a high correlation between the measured gravity in the system of public transport, and commuting to work and school. This means that gravity studies in public transport can successfully replace data on actual flows for the regions or time periods for which the latter data are unavailable. In countries or regions with easy access to timetable databases, such studies are much simpler and cheaper than an investigation of commuting to work or school.

The method also has drawbacks. In Poland, public transport only accounts for approximately $27 \%$ of pedestrian travel (Centrum Badań i Edukacji Statystycznej GUS 2015). What is more, in the last few years, the structure of the traveller clientele has clearly changed (see Table 2). The number of passengers has dropped considerably, especially among those commuting to work. This is correlated with a

Regional Statistics, Vol. 7. No.1. 2017: 063-077; DOI: 10.15196/RS07104 
large increase in the number of cars. Thus, the gravitation studied does not comprise all trips. In poorly accessible areas, which are forced to use individual transport, establishing the actual interactions by analysing gravity in public transport is likely to generate errors.

Table 2

Changes in the number of passengers on regular bus transport and the motorisation rate in 2010 and 2015

\begin{tabular}{l|l|r|r|r}
\hline \multicolumn{2}{l|}{} & \multicolumn{1}{|c|}{2010} & \multicolumn{1}{c|}{2015} & $2010=100.0$ \\
\hline Passengers carried by regular & Total & 476,055 & 347,777 & 73.1 \\
(commercial) transport & With monthly employee tickets & 40,975 & 27,279 & 66.6 \\
(in thousand passengers) & With monthly student tickets & 215,799 & 168,901 & 78.3 \\
\multicolumn{2}{l}{ Motorisation rate (number of cars / 1000 population) } & 451 & 539 & 119.5
\end{tabular}

Source: authors on the basis of GUS 2011, 2016.

Another problem is the concentration of the public transport network along the main transport routes. Towns located near major roads are characterised by 'excessive' accessibility and vice versa. For example, in the Pomorskie Voivodship, out of the general number of 1753 rural localities (villages) as many as 318 were not served by public transport. Most of them were small villages with an average population of 200, lying outside of the system of national and regional roads.

The multipliers of the connection index may raise some discussion. A connection index is built to reflect a potential accessibility and does not directly take into account the issue of capacity and its utilisation. The authors decided to allocate the highest weight for railway connections followed by city transportation as they are proven in different studies to be more reliable and also cheaper than regional bus connections. What is important about railways is that some real-life connections and relations are deeply rooted in historical accessibility, and one must be aware that buses in some rural areas have been in operation since the 1970s whereas railways have provided accessibility and shaped relations for more than 100 years.

Finally, account must be taken of a problem specific to Poland, namely, the low availability of passenger information: a lack of published timetables, or even an absence of timetables on bus stops, as well as the inaccuracy of the data obtained from the public offices that issue licences to passenger carriers. As a result of the lack of passenger information, obtaining the timetables proved to be the most difficult and labour intensive part of our research.

\section{REFERENCES}

Amin, A.-Thrift, N. (2002): Cities: reimagining the urban Polity Press, Cambridge. CENTRUM BADAŃ I EDUKACJI STATYSTYCZnEJ GUS (2015): Badanie pilotażowe zachowań komunikacyjnych ludności w Polsce, etap III - raport końcowy Jachranka.

Regional Statistics, Vol. 7. No.1. 2017: 063-077; DOI: 10.15196/RS07104 
CHOJNICKI, Z. (1966): Zastosowania modeli grawitacji i potencjału w badaniach przestrzenno-ekonomicznych Studia KPZK PAN 14.

ESPON (2007): Study on Urban Functions. ESPON Project 1.4.3. Final Report ESPON, Coordination Unit, Luxembourg. http://www.espon.eu/export/sites/default/ Documents/Projects/ESPON2006Projects/StudiesScientificSupportProjects/U rbanFunctions/fr-1.4.3_April2007-final.pdf (downloaded: 21.02.2016).

Gruchociak, H. (2012): Delimitacja lokalnych rynków pracy w Polsce Przegląd Statystyczny 59 (2): 277-297.

GUS (2011): Transport - wyniki działalności w $2010 \mathrm{r}$. Warszawa.

GUS (2016): Transport. Wyniki działalności w $2015 \mathrm{r}$. Warszawa.

GuZIK, R. (2003): Przestrzenna dostępność szkolnictwa ponadpodstawowego Instytut Geografii i Gospodarki Przestrzennej UJ, Kraków.

GUZIK, R. (ed.) (2012): Czynniki i ograniczenia rozwoju miast województwa pomorskiego w świetle relacji przestrzennych i dostępności komunikacyjnej Urząd Marszałkowski Województwa Pomorskiego, Gdańsk.

GuZIK, R.-KoŁoś, A. (2015): Dostępność komunikacyjna In: GuZIK, R.-Kotoś, A. (ed.) Relacje funkcjonalno-przestrzenne między ośrodkami miejskimi i ich otoczeniem w województwie pomorskim pp. 217-268., Pomorskie Studia Regionalne, Urząd Marszałkowski Województwa Pomorskiego, Gdańsk.

GuZiK, R.-Koloś, A.-GWosdz, K.-Biernacki, W.-DziateK, J.-KOCAJ, A.-PANECKANiepsuj, M.-Wiedermann, K. (2016): Dostępność, relacje i powiązania przestrzenne w Miejskim Obszarze Funkcjonalnym Olsztyna Instytut Geografii i Gospodarki Przestrzennej Uniwersytetu Jagiellońskiego, Kraków.

GuZik, R.-Zborowski, A.-KoŁoś, A.-MiceK, G.-GwosdZ, K.-TrZePACZ, P.Chaberko, T.- Kretowicz, P.-Ciechowski, M.-DeJ, M.-Grad, N. (2010): Dostępność komunikacyjna oraz delimitacja obszarów funkcjonalnych In: DOMAŃSKI, B.-NOWORÓL, A. Małopolskie miasta - funkcje, potencjał $i$ trendy rozwojowe pp. 88-134., Małopolskie Obserwatorium Polityki Rozwoju, Kraków.

PÁlóczi, G.-PÉnzes, J.-HurbáneK, P.-Halás, M.-KlapkA, P. (2016): Attempts to delineate functional regions in Hungary on the basis of commuting data Regional Statistics 6 (1): 23-41.

PARR, J. (2005): Perspectives on the city region Regional Studies 39 (5): 555-566.

POOLER, J. (1987): Measuring geographical accessibility: a review of current approaches and problems in the use of population potentials Geoforum 18 (3): 269-289.

SiŁkowskA, I.-BORAwskA, J.-CirockA, M.-DziubaŁtoskA, A.-FijaŁowskA, A.Gajewski, R.-GostomCZYK, D.-PleszKun, A.-KLEINA, R.-PUZDRAKIEWICZ, K.-SZLACHETKO, J.-WILK, D. (2016): Wyznaczanie granic obszarów metropolitalnych w świetle wybranych koncepcji naukowych In: SZLACHETKO, J.H.-GAJEWSKI R. (eds.) Instytucjonalne formy współdziałania jednostek samorządu terytorialnego na obszarach metropolitalnych pp. 63-70. Wydawnictwo Uniwersytetu Gdańskiego, Gdańsk.

ŚLESZYŃSKI, P. (2012): Struktura przestrzenna dojazdów pracowniczych w Polsce w 2006 t. In: Rosik, R.-WiśnIEWski, R. (eds.) Dostępność i mobilność w przestrzeni pp. 23-34, IGiGP PAN, Warszawa.

Regional Statistics, Vol. 7. No.1. 2017: 063-077; DOI: 10.15196/RS07104 
ŚLESZYŃSKI, P. (2013): Delimitacja Miejskich Obszarów Funkcjonalnych stolic województw Przegląd Geograficzny 85 (2): 173-197.

ŚLESZYŃSKI, P. (2014): Delimitation and typology of functional urban regions in Poland based on commuting 2006 Geographia Polonica 87 (2): 317-320.

ŚLESZYŃSKI, P. (2016): Naukowe podstawy i praktyczne problemy klasyfikacji i delimitacji obszarów metropolitalnych In: SZLACHETKO, J. H.-GAJEWSKI, R. (eds.), Instytucjonalne formy współdziałania jednostek samorządu terytorialnego na obszarach metropolitalnych pp. 71-90., Wydawnictwo Uniwersytetu Gdańskiego, Gdańsk.

SMẼTKOWSKI, M.-JALOWIECKI, B.-GORZELAK, G. (2009): Obszary metropolitalne w Polsce: problemy rozwojowe i delimitacja, Raporty i analizy EUROREG 1/2009, Warszawa.

STEWART, J. Q. (1942): A measure of the influence of population at a distance Sociometry 5 (1): 63-71.

VICKERMAN, R.W. (1974): Accessibility, attraction and potential: a review of some concepts and their use in determining mobility Environment and Planning A 6 (6): 675691.

Regional Statistics, Vol. 7. No.1. 2017: 063-077; DOI: 10.15196/RS07104 